GLOBAL WATER PATHOGEN PROJECT

PART FOUR. MANAGEMENT OF RISK FROM EXCRETA AND WASTEWATER

\title{
SEPTIC SYSTEMS
}

\section{Anthony A. Adegoke}

Durban University of Technology

Durban, South Africa

Thor-Axel Stenstrom

Durban University of Technology

Durban, South Africa 


\section{Copyright:}

\section{cc) (1) (2) \\ BY SA}

This publication is available in Open Access under the Attribution-ShareAlike 3.0 IGO (CC-BY-SA 3.0 IGO) license (http://creativecommons.org/licenses/by-sa/3.0/igo). By using the content of this publication, the users accept to be bound by the terms of use of the UNESCO Open Access Repository (http://www.unesco.org/openaccess/terms-use-ccbysa-en).

\section{Disclaimer:}

The designations employed and the presentation of material throughout this publication do not imply the expression of any opinion whatsoever on the part of UNESCO concerning the legal status of any country, territory, city or area or of its authorities, or concerning the delimitation of its frontiers or boundaries. The ideas and opinions expressed in this publication are those of the authors; they are not necessarily those of UNESCO and do not commit the Organization.

\section{Citation:}

Adegoke, A. and Stenstrom, T. 2019. Septic Systems. In: J.B. Rose and B. Jiménez-Cisneros, (eds) Global Water Pathogen Project. http://www.waterpathogens.org (J.R. Mihelcic and M.E. Verbyla) (eds) Part 4 Management Of Risk from Excreta and Wastewater) http://www.waterpathogens.org/book/septic-systems Michigan State University, E. Lansing, MI, UNESCO.

https://doi.org/10.14321/waterpathogens.59

Acknowledgements: K.R.L. Young, Project Design editor; Website Design: Agroknow (http://www.agroknow.com)

Last published: February 8, 2019 


\section{Summary}

A septic system is a self-contained, underground wastewater treatment system. A typical onsite (occurring at the same vicinity where waste is produced) septic system consists of two main parts; a septic tank that is followed by another treatment stage that in many cases is a subsurface soil absorption system. The treatment performance is based on providing sufficient hydraulic residence time for the wastewater that is long enough in the tank to allow for separation of solids from liquids. To enhance the solids separation process, the tank can be designed with a 2- or 3chamber configuration. The outlet from the final chamber is to the subsurface drainfield or to other additional treatment alternatives. Mechanisms for the reduction of pathogens in a septic tank include collection and settling in the sludge, as well as decay or digestion. Reduction of indicator bacteria may be as high as 4 to $8 \log 10$ and virus reduction varied from 0 to $2 \log 10$ units. Other variables and enhancements are discussed throughout the chapter.

\subsection{Septic Systems Overview}

\subsection{Brief Technology Description}

A septic system is a self-contained, underground wastewater treatment system. A typical onsite (occurring at the same vicinity where waste is produced) septic system consists of two main parts; a septic tank that is followed by another treatment stage that in many cases is a subsurface soil absorption system, Figure 1 (e.g., a drainfield, constructed wetland, filter, duck pond, or some type of aerobic treatment). The septic tank is a watertight chamber used for the storage and treatment of blackwater, greywater, and the resulting sludge. It is usually constructed of concrete or fiberglass, PVC, or other types of plastics and contains both an inlet and an outlet pipe. Wastewater flows from the user interface to the septic tank through a piped conveyance system as shown in Figure 2.

The choice of the post-tank treatment system will depend on the treatment of an individual system (Pundsack et al., 2001; Papadopoulos et al., 2011; Sharma et al., 2014). One advantage of septic systems is that they are simple in design and conventional ones require no input of chemicals or energy, which make them generally less expensive to install and maintain. Figure 2 shows the location of septic tank in the entire sanitation service chain.

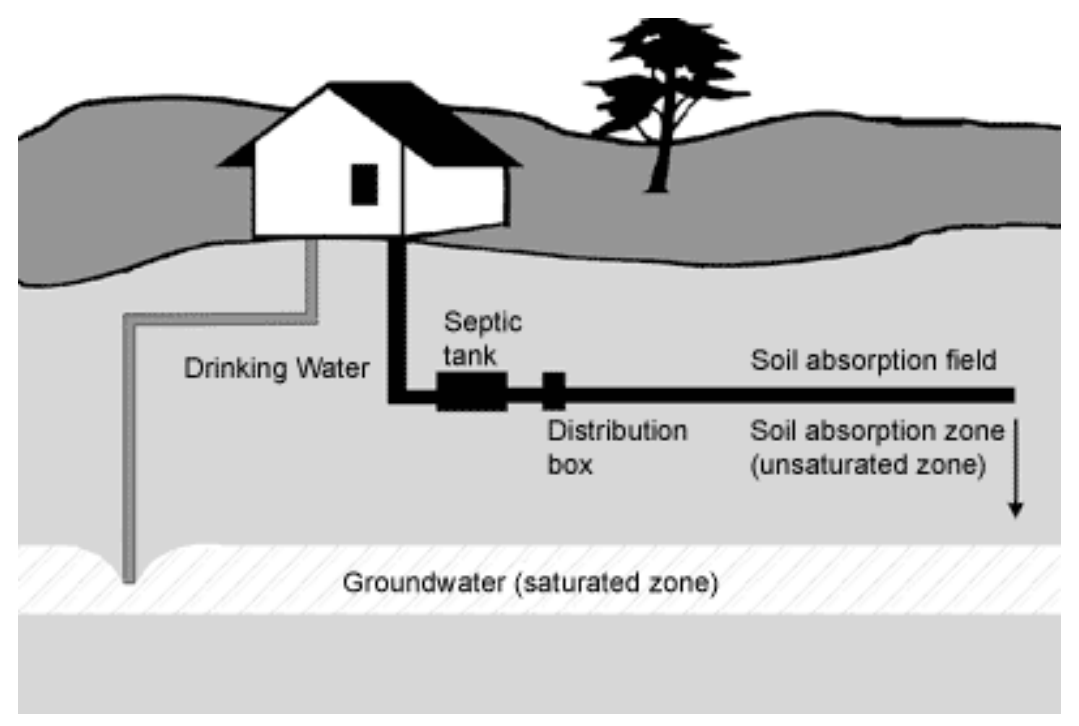

Figure 1. Septic tank and drainfield soil absorption system following the septic tank for onsite wastewater management (figure reproduced with permission of Purdue University, Department of Crop, Soil, and Environmental Sciences, Chapter IV. Soils and Homesites, https://www.agry.purdue.edu/soils_judging/new_manual/ch4-homesite-Onsite.html\#sub1)

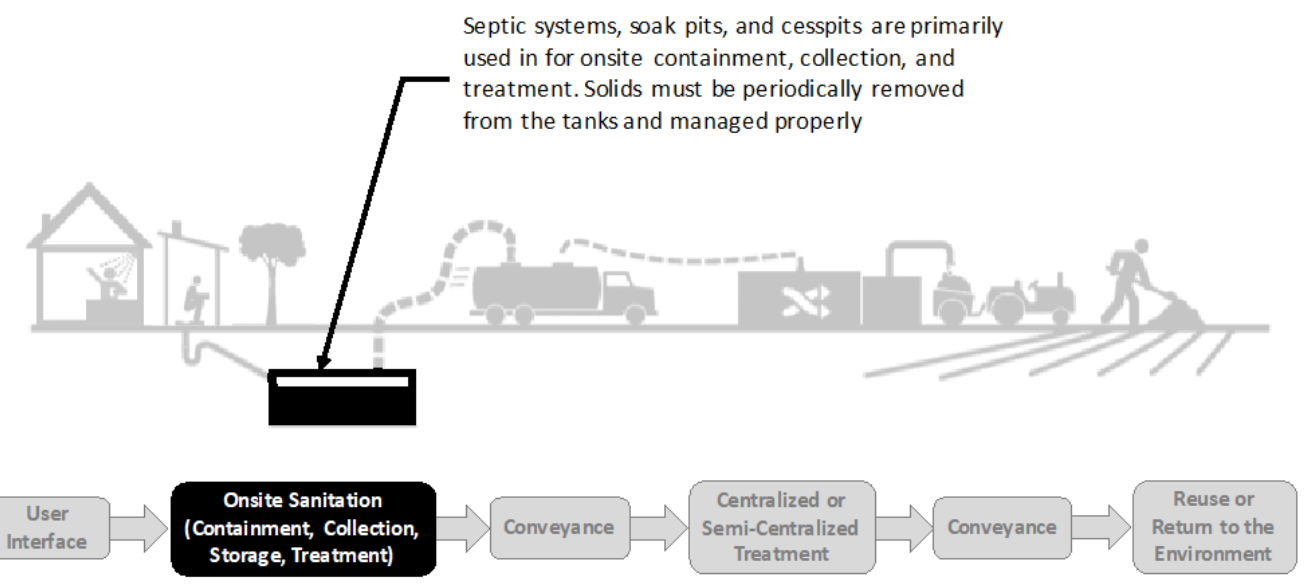

Figure 2. Schematic showing the position of septic tank in the overall sanitation service chain 
The design of the septic tank is based on factors such as the number of users, volume of water entering the system, temperature, desludging frequency, and the desired purpose on the treated wastewater (e.g. reuse). Details on design and operation of these systems have been published earlier (e.g., Otis et al., 1980; Siegrist et al., 2000; Tilley et al., 2014). The design and operation take into cognizance hydraulic residence time and solid separation.

- The treatment performance is based on providing sufficient hydraulic residence time for the wastewater that is long enough in the tank to allow for separation of solids from liquids.

To enhance the solids separation process, the tank can be designed with a 2- or 3-chamber configuration. The outlet from the final chamber is to the subsurface drainfield or to other additional treatment alternatives.

In a conventional septic tank, the wastewater is normally separated into three layers inside the tank (Figure 3). Materials less dense than water (such as greases, fats, and oils) float to the top forming a layer of scum. Solids denser than water settle to the bottom of the tank forming a layer of sludge. This leaves a middle layer of partially clarified wastewater. It is within this middle layer that the outlet is located to the preceding chamber or outlet. The layers of sludge and scum remain in the septic tank where autochthonous bacteria from the wastewater break down some of the solids by anaerobic processes. The scum and sludge that is not broken down will remain in the tank until the contents are emptied (approximately $50 \%$ of the sludge that accumulates is not degraded in the tank).

There is need for maintenance of septic systems, as failure to do this would make them hotspots for the discharge of pollutants (Richards et al., 2016). The maintenance required for a septic system depends on the configuration. Some septic systems contain parts that require replacement with time e.g. effluent filters, to guarantee effective removal of pathogens and other pollutants (Heistad et al., 2009). For example, in a study to assess removal of phosphorus, bacteria, and viruses by an onsite system containing a septic tank, a pressure-dosed vertical flow biofilter, and an upflow filter unit with lightweight clay aggregates a progressively decreased phosphorus removal by the filters in the end of and after a 5-year design capacity was exceeded (Heistad et al., 2009). In addition, there was a substantial decrease in the removal efficiency of $E$. coli during three years of operation, from $5.6 \log _{10}$ to $2.6 \log _{10}$ reduction.

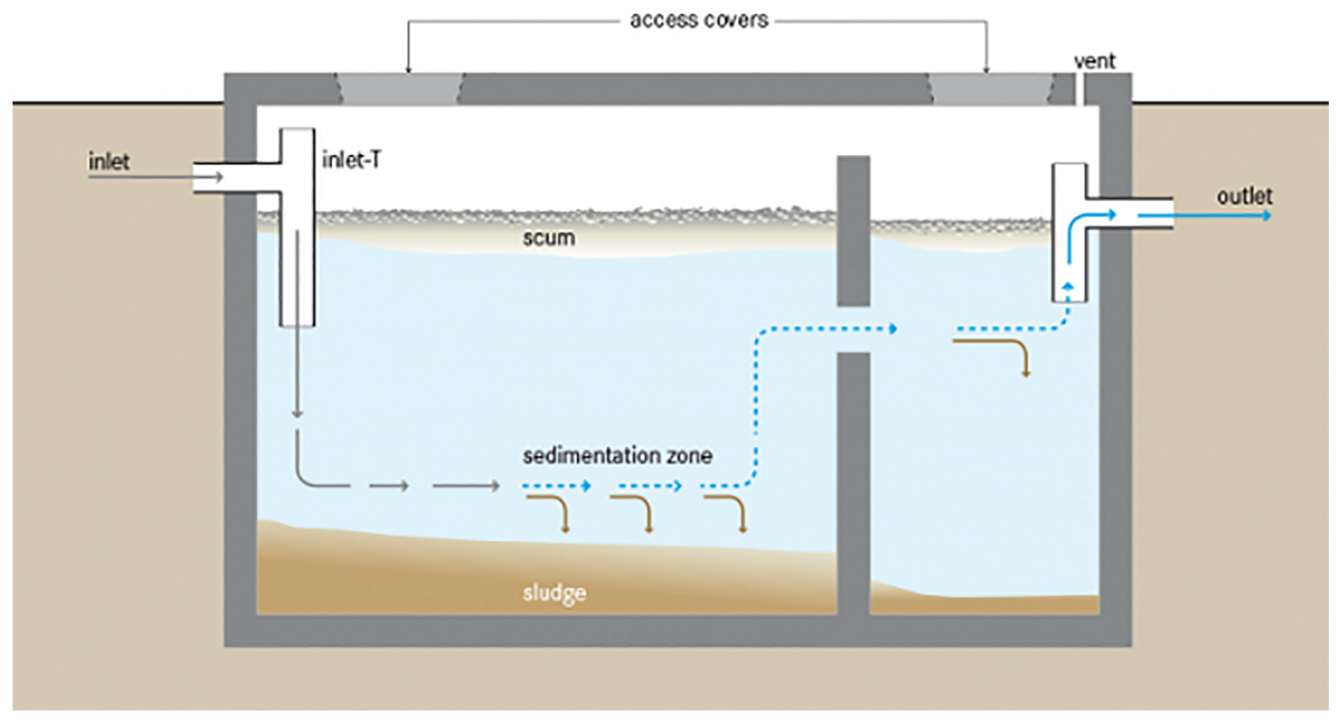

Figure 3. Septic tank showing three distinct layers (scum (oil, fats, and grease), clarified water, and sludge (diagram reprinted from Tilley et al. 2014 with permission)

The layer of clarified liquid flows from the septic tank through an outlet pipe to a soil absorption system or some other type of distribution device. A standard soil absorption system is referred to as a drainfield (also known as a leachfield, disposal field) and is typically a series of trenches or a subsurface bed (lined with gravel or course sand) 0.5 to 1 $\mathrm{m}$ below the ground surface (Figure 1). Perforated pipes or drain tiles run through the trenches to distribute the wastewater. In the drainfield the wastewater slowly trickles from the pipes into the gravel/soil and percolate further down through the subsurface soil. The gravel and soil act as a filter, employing a combination of filtration, adsorptive, and biological processes to further remove chemical and microbial constituents.

Groundwater may be impacted by septic systems depending on quality of system design and maintenance, the density of tanks per unit area, geology, and the functionality of soil absorption system if present (Pang et al., 2003; Vijay et al 2011; Banda et al., 2014; Sowah, 
2017). The potential for enhanced pathogen reduction in the unsaturated zone before septic tank effluent reaches the groundwater depends on factors such as the vertical distance to the groundwater surface, type and texture of the soil, temperature, and $\mathrm{pH}$.

\subsection{Types of Septic Systems}

One variant of the conventional septic tank that provides increased settling and sludge contact is an Anaerobic Baffled Reactor (ABR) (Figure 4, for more information see Tilley et al., 2014). This system uses processes of settling and anaerobic digestion that are similar to those described in the chapter on Anaerobic Upflow Sludge Blanket Reactors. In this system, an increased number of chambers and a forced liquid flow through the accumulated sludge results in enhanced reduction of organics and solids compared to a conventional septic tank. An anaerobic filter is a further adaptation that incorporates a filter media (e.g. crushed rock or manufactured plastic) into a final chamber. After the first chamber, the wastewater is forced to flow up through the filter as a final polishing step (see chapter on Media Filters).

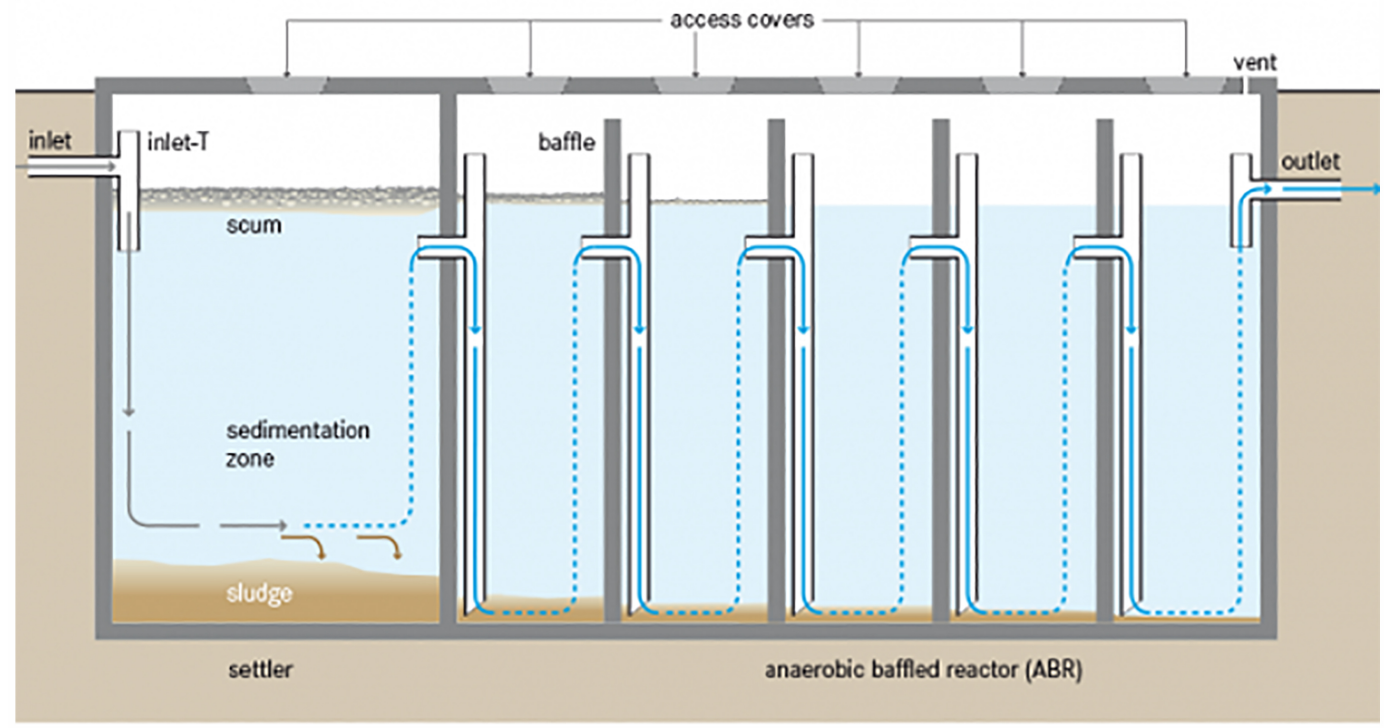

Figure 4. Anaerobic Baffled Reactor septic tank showing location of baffles and three distinct layers (scum (oil, fats, and grease), clarified water, and sludge (diagram reprinted from Tilley et al. 2014 with permission)

The modified septic tank-anaerobic filter unit depicted in Figure 5 is an example of another design to enhance effluent quality. Modified septic systems can contain other coupled mechanisms like anaerobic digestion and disinfecting chambers. Some have modifications such as vertical baffled septic tank containing filter and a chamber for disinfection (Anil and Neera, 2016).

Variants of the drainfield may include applications such as low-pressure drainfields and the intermittent aeration systems. The low pressure drainfields have two categories, which are recognized based on the strength of the wastewater dosed and are low-pressure pipe and shallow narrow drainfields. The low-pressured pipe can be installed in a trench whereby stones or gravels support the pipes. This is unlike a shallow narrow drainfield, which are usually set in place beneath a shallow trench (USEPA, 1992; Uebler, 1982).
Drainfields, as systems for waste treatment, have essentially 3 modifications: dry well systems, mound-type drain fields and chamber-type systems. Dry well systems utilize large pits filled with stones, rocks or gravel for filtration instead of perforated pipes. It is a long lasting traditional horizontal drain fields. Mound drain systems are more expensive to run as additional system components may be needed to pump wastewater to the filtration part, which is usually positioned above the ground surface. The soil factor and design of construction used determines the durability in the mound drain system. The last, but one of the newer methods, is the chamber systems, which hold fluids in a mini-reservoir, allowing it to percolate into the ground without an expected filtering bed containing gravels. It is easy to install, but it does not last long and requires regular monitoring. 


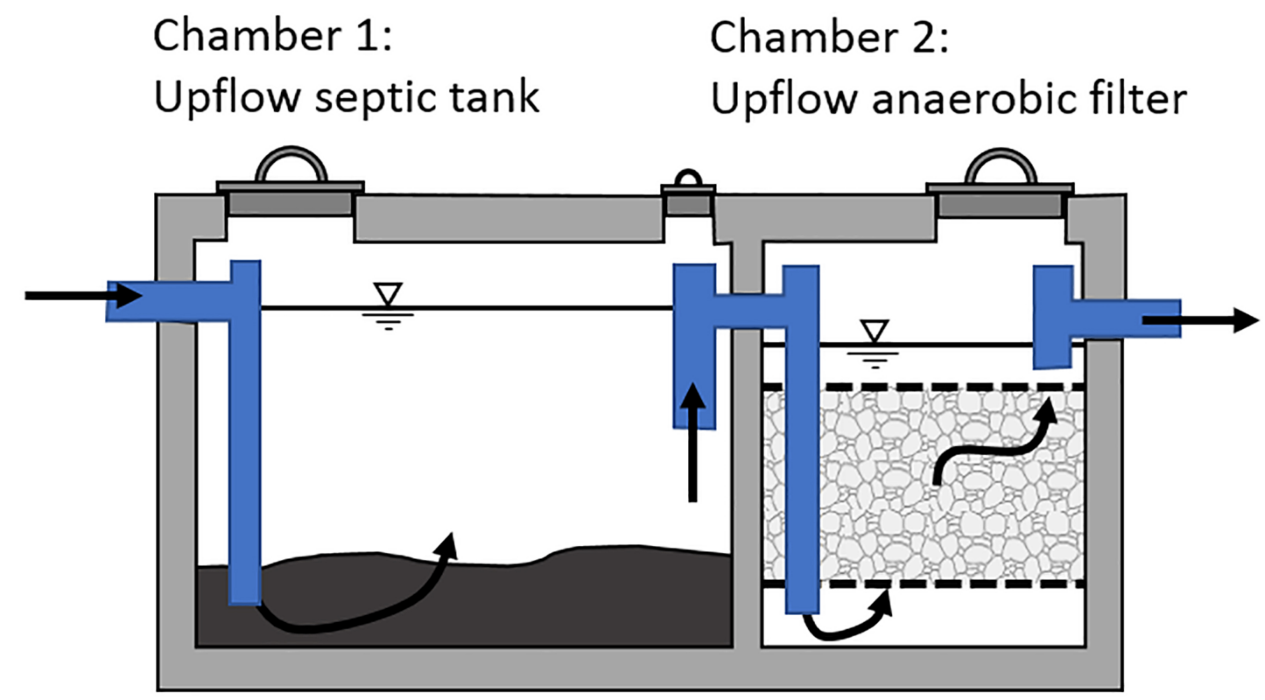

Figure 5. Modified septic tank-anaerobic filter unit as a two-stage onsite domestic wastewater treatment system

\subsection{Inputs and Outputs from Septic Systems}

The input to the septic tank includes urine, faeces, flush water, dry-anal cleansing materials, anal cleansing water and/or greywater. Optimally a conventional septic tank is capable of removing close to $50 \%$ of the input organic materials and suspended solids that then undergoes further degradation in the sludge layer by anaerobic digestion, and further remove about $30 \%$ of the nitrogenous waste from domestic wastewater (USEPA, 2000). The rate of digestion increases with temperature, with a maximum temperature reported to be around $35^{\circ} \mathrm{C}$ (Franceys et al. 1992), though anaerobic mesophilic treatment is possible (Marañón et al., 2006). Removal of pathogens varies and largely depends on die-off in the retained sludge and the removal of suspended solids (emptying). The fraction of pathogens that remain in the liquid phase will enter the drainfield or additional addon treatment steps. Further reduction of pathogens will depend on the design and location of the system.
Figure 6 shows the illustrative inputs and outputs from septic systems. Pathogen concentrations in the effluent are expected to be less than those in the influent. No increase of virus or parasite concentration will occur. However, in some situations, an increase in some of the bacterial pathogen concentrations between the influent and effluent may occur due to regrowth. This mainly refers to Salmonella and entero-pathogenic E. coli based on factors such as temperature and fraction of easily degradable organic material. For example, Appling et al. (2013) reported that $E$. coli concentration was 100 -fold higher in the septic tank effluent than influent wastewater, due to regrowth under summer temperature conditions.

The number of users, user infectivity, and different type of activities affects the diversity of pathogens, volume of treated wastewater, and chemical composition of the wastewater entering a septic tank (Butler and Davies, 2004). Pathogenic inputs to a septic tank may further vary over the day and may peak in the morning, when household members are just beginning their daily activities. Other variations are due to season and household events.

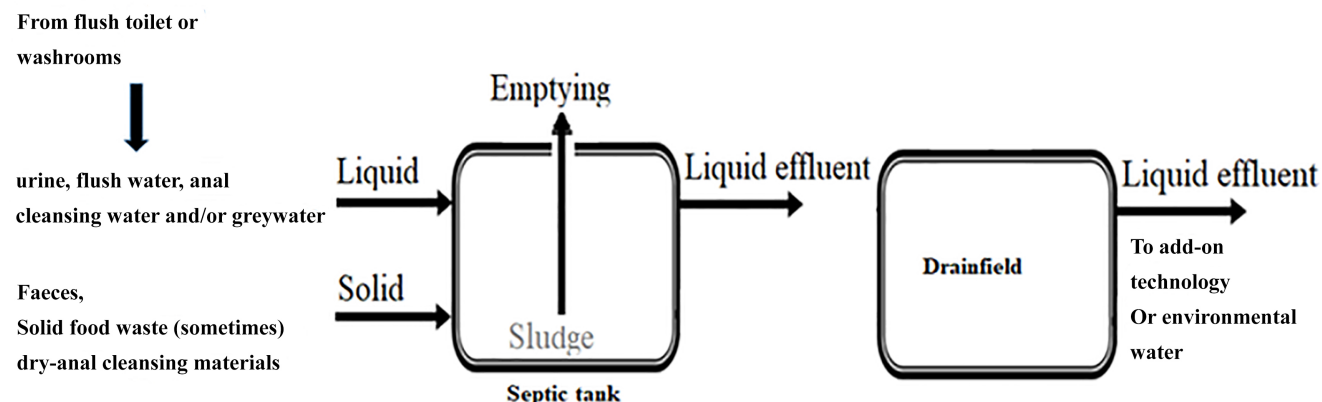

Figure 6. Illustrative inputs and outputs from a septic system 


\subsection{Factors Affecting Pathogens in Septic Systems}

\subsection{Summary of Pathogen Removal Mechanisms}

Mechanisms for the reduction of pathogens in a septic tank include collection and settling in the sludge, as well as decay or digestion. Other add-on treatment steps that are located after the septic tank include filtration (soil absorption systems and anaerobic/sand/peatfilter/microfiltration/ ultrafiltration), aerobic treatment, anoxic/anaerobic treatment and in a few cases chlorination. These add-ons will enhance the overall pathogen reduction in septic systems (Papadopoulos et al., 2011; Sharma et al., 2014; Purnell et al., 2016). After emptying the sludge is usually conveyed off-site for further treatment, disposal, and/or reuse as a soil amendment (see Chapters on Conveyance and Sludge Management). The efficacy of pathogen reduction in septic systems and a soil absorption system is affected by the type and concentration of pathogens in the influent, physical/chemical factors as well as design factors of the septic tank. In addition, site-specific properties such as soil type and distance to the groundwater table, properties of the biomat (a permeable layer of partially decomposed organic waste with microorganisms and their by-products for biodigestion), predation, dissolved oxygen, temperature, moisture/rainfall, and $\mathrm{pH}$ will also affect.

\subsection{Physicochemical/biological factors}

Post septic tank treatment will be affected by physical, chemical and biological processes that impact on pathogen removal. Temperature, light intensity or UV, $\mathrm{pH}$, soil types, infiltration surfaces, and salinity may affect pathogen concentrations depending on the post-treatment methods applied (Stevik et al., 2004; Chabaud et al. 2006; Cooper et al., 2016). The persistence of different microbial species and strains varies in relation to these factors. Pathogens that are larger (e.g., helminths) or adsorbed to particles will primarily settle to the bottom of the tank. Chemical disinfectants, including bleach used to wash the toilets at the user interface, may affect the pathogen survival in the septic tank, drainfield, and the surrounding environment that receives treated effluent (Chabaud et al., 2006). The impact of household disinfectants will of course depend on the flush/flow quantities (dilution) level of water entering the system.

As the septic system design affects the effectiveness of the treatment process, other factors such as system age, type of tank, tank management, number of users, health of the users also determines the input and output of the pathogens. A study by Richard et al. (2016) measured effluent from 32 residential septic tanks in Northeast Scotland and an adjacent river. That study reported the following concentrations in the tank effluent for total coliforms $\left(10^{3}-10^{8} \mathrm{MPN} / 100 \mathrm{~mL}\right)$ and E. coli $\left(10^{3}-10^{7}\right.$ MPN/100 mL). The authors specifically identified tank condition, and number of users as the factors that affected the effluent concentration of the tanks with further impact on the adjacent river. The retention time of the wastewater from the source to its release to the environment is one factor that determines the reduction of pathogens and the effectiveness of post-tank treatment in the soil absorption system (Cave and Kolsky, 1999).

\subsection{Specific site properties of the septic systems}

Filtration efficiency in soil absorption systems essentially depends on the size and shapes of the microorganisms in addition to the size distribution of soil particles. Small size viruses will be removed to a less extent by filtration than bacteria and parasitic protozoa with their larger sizes. Wastewater retention capacity in soil absorption systems may also be associated with the vertical velocity of the tank effluent, depending on the site gradient, hydraulic conductivity, and porosity of the subsurface media. Factors such as the distance with unsaturated flow from the septic system to the groundwater table, the type of soil (which in turn determines the rate of percolation), and site topography all influence pathogen transport (Wolf et al., 2006; de Oliveira et al., 2016) (see also chapter on Waterless Onsite Systems: Pit Toilets (Latrines)).

The bacterial adsorption may be sustained by released metabolites with adhesive properties (capsular material, flocculants), permanently attaching the microorganisms to the particles (Stevik et al. 2004). Bacterial attachment rate at the soil-water interface can be predicted analytically using a combined rate equation, which is associated with changes in solution chemistry (Zhang et al., 2013). The resulting larger particle-microorganism flocs will further reduce soil penetration and microbial transport. These filtration processes are influenced by a range of physical and chemical properties of the filter media, the presence of organic matter, temperature, hydraulic loading, ionic strength, $\mathrm{pH}$, surface charge of particles, and microbial concentrations.

The local hydrogeological conditions of the drainfield are further determinants of the subsequent horizontal flow of pathogens in the saturated zone. This is closely connected to the fracture conditions of the underlying rocks as it determines filtration efficiency (Borchardt et al. 2011). Of the total reduction in an onsite soil absorption system, soil filtration was reported to account for approximately $0.92 \log _{10}$ of $E$. coli reduction, which implies 
die-off of only $0.06 \log _{10}$ of this indicator. In contrast, for FRNA bacteriophages used as a viral indicator, adsorption/filtration accounted for only $0.35 \log _{10}$ of the overall reduction while $0.26 \log _{10}$ reductions were due to inactivation (Pang et al., 2003).

The water holding capacity of soil is also of major importance because it affects the contact time of the pathogen in the soil. In addition, with increasing subsurface particle size, pathogen penetration will also increase and affect the effectiveness in septic system for pathogen removal (Harrison et al. 2000; Gill et al., 2001).

Closely compacted soils like clays normally hinder the septic tank effluent from infiltrating vertically in the subsurface, with sufficient time for adsorption leading to ample removal of pathogens before the effluent passes. The adsorption of microorganisms to clay, which is aided by the opposite charges between the clay $(+)$ (fixed positive charges can be exposed in the crystal gitter even if clay minerals may have a net negative charge) and the pathogens (-) as ionic attractions (Stevik et al. 2004). However, the fine particle size of clays may lead to clogging which is why clayey soils may not be appropriate for location of a soil absorption system.

\subsection{Presence of Biomat}

A biomat is functionally the layer directly underneath the point of subsurface discharge from the septic tank effluent to the soil absorption system that can reduce the permeability. A biomat may vary in size and may be $2 \mathrm{~cm}$ thick on top of the soil under where the wastewater begins to infiltrate (Kristiansen, 1981; Beal et al., 2006). Pathogens trapped in the soil layers because of the biomat would essentially be retained or killed in the upper soil layer of the soil absorption system (Beal et al., 2006; Unc and Goss, 2003).

\section{5 Predation}

As it in municipal wastewater treatment plants, predation within the septic tank will also reduce the total heterotrophic community in the wastewater, beside interspecific competition (Kadam et al. 2008). Autolysis as well as predation affect the concentration of remaining pathogens in septic system (Thingstad, 2000; Bell et al., 2009) and those released into the environment but the actual impact of these factors are unclear.

\subsection{Dissolved Oxygen}

Septic tanks are primarily anaerobic environments because of the high amount of organic matter present in the tank. Oxygen levels can increase though in the soil absorption system due to, for example infiltrating rainwater. In the unsaturated zone the presence of dissolved oxygen (DO) typically prevails, which may affect the die-off of some pathogens (Stevik et al., 2004).

\subsection{Temperature}

Inactivation of bacteria and viruses in wastewater may depend on temperature and dilution (Vinnerås et al., 2008). Temperature in a septic tank is impacted by the composition of the influent (inputs of blackwater versus heated or cooled greywater). Elevated temperature is expected to increase the death of some pathogens (NOAA, 2011; Cooper et al., 2016; Heger, 2017). Activities of other organisms are reduced in low temperatures leading to reduced predation (Bell et al., 2009). At ambient environmental temperatures below $0^{\circ} \mathrm{C}$, the treatment process of bacteria can be negatively affected but modern septic system located in temperate regions are normally adequately insulated from extreme cold weather to prevent such failures (Wallace, 2000).

\section{$3.8 \mathrm{pH}$}

$\mathrm{pH}$ is not normally considered as an essential factor in determining the fate and reduction of pathogens in a septic tank. However, in a soil absorption system, $\mathrm{pH}$ does influence the retention of viruses and bacteria through adsorption to soil. Optimum viral retention is reported to take place between pH 3 to pH 7 (Jimenez et al., 2010).

\subsection{Moisture and rainfall}

With regards to adsorption of pathogens in subsurface soil absorption system, an important factor is rainfall intensity and duration (Pundsack et al. 2001, Stevik et al. 2004). For example, detachment (by rainfall) of viruses has been observed from $60 \mathrm{~cm}$ of fine sand dosed with septic tank effluent (Nicosia et al., 2001). The intensity of a precipitation event thus affects the holding capacity in the soil depending on its texture. In this case, clay soil may retain viruses better than other soil types (Lusk et al., 2014). Viruses may still retain their infectivity in an adsorbed state, if there is enough moisture to preserve the protein coat (Bosch et al., 2006). Furthermore, with higher inputs of rainfall, the ionic strength of the septic tank effluent being released into a soil absorption system will decrease and may detach and remobilise pathogens (Okoh et al. 2010).

\subsection{Chlorination and Ultraviolet radiation (UV)}

Use of chlorination or ultraviolet radiation (UV) to treat septic tank discharge is not typically employed by homeowners, as chlorination is usually not encouraged and UV systems felt expensive. It does however occur in the U.S. for some community septic systems that are required to obtain discharge permits. The selection of appropriate disinfection methods for the post-treatment of wastewater pathogens in a septic system depends on the size of the septic system and the types of household wastes being generated (USEPA, 2003). For UV, pathogen die-off depends on the duration of exposure and the measure of light intensity that reaches the pathogens within the septic system. (see section on disinfection) Because a septic system is closed, only artificially installed UV units can provide guaranteed effects on the pathogens. 


\subsection{Summary of Data on Pathogens, Epidemiology and Health Risk Evidence Associated with Septic Tank and Soil Absorption Systems}

The health risks are far greater when the system are malfunctioning (Levett et al., 2010). In general, treatment only by a septic tank is not considered as a significant barrier against pathogen transmission. The estimated reduction value for pathogens in a septic tank alone is less than $0.5 \log _{10}$ (WHO, 2006). However, pathogen reduction can be greatly enhanced when a septic tank is properly maintained and incorporated with a properly designed and sited soil absorption system. Negative impact of septic tank with soakaway are exemplified by Keegan et al. (2014).

The $\log _{10}$ redction for septic tanks and septic systems on some bacterial indicators and different assessed pathogens is depicted in Figure 7. Reduction of indicator bacteria may be as high as 4 to $8 \log _{10}$ in a properly maintained septic tank integrated with a soil absorption system but may also be highly variable. Nnaji (2011) reported a $\log _{10}$ reduction in E. coli concentrations that ranged from 0 to 4.35 in a system consisting of a septic tank. variation was depending on the design approach. Sometimes the effluent values of E. coli in septic tank effluent have been reported to exceed the influent concentrations (e.g., Nnaji, 2011; Appling et al. 2013). This can depend on several factors like concentration variations, non-matching of samples and/or regrowth in septic tank scum and sludge. measured virus reduction, as exemplified in Figure 7 , varied from 0 to $2 \log _{10}$ units. Helminth egg concentrations will be greatly reduced in the liquid phase due to gravity settling and concentrate in the septic tank sludge phase in properly maintained units. If they would enter a preceding soil absorption system, they would during most circumstances be filtered out and not impact the groundwater. Protozoan cysts and oocysts are also larger in size than viruses and bacteria and are expected to be totally removed in a properly designed and sited soil absorption system. This includes systems with only a septic tank (Appling et al., 2013; Nnaji, 2011; HeinonenTanski and Savolainen, 2003), septic tank integrated with a soil absorption system (Katz et al., 2010) and modified septic systems (Purnell et al., 2016; Sharma and Kazmi, 2015; Sharma et al., 2014; Papadopoulos et al., 2011; Mbuligwe, 2005).

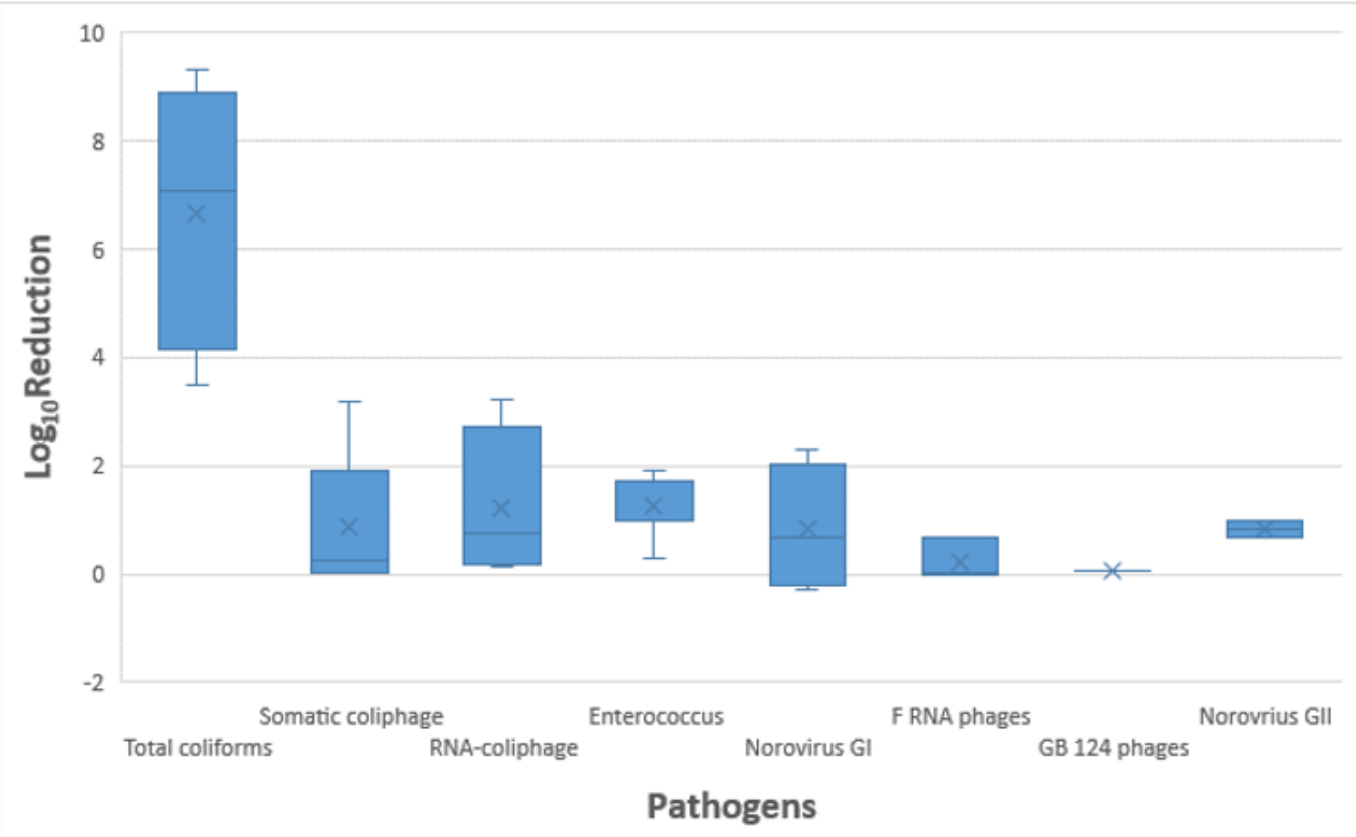

Figure 7. Selected reported $\log 10$ reduction of different pathogens observed in a range of septic systems

In a cross-sectional study conducted based on the effects of siting a septic system at distances of $<30 \mathrm{~m}$ and $\geq 30 \mathrm{~m}$ close to source of groundwater supply, Banda et al. (2014) found that about 33\% of groundwater samples were contaminated. Bishop and Inabo (2015) also reported the effect of distance of wells to a septic system based on the microbial contamination of well water. Various etiological agents and health outcomes have been closely associated with exposure to discharge from septic tanks, which includes hepatitis A, typhoid, and acute gastroenteritis from various pathogens (Borchardt et al., 2003; Borchardt et al., 2011; CDC, 2015).

When the septic tank is not integrated with a soil absorption system or when the system is located too close to groundwater wells or in areas with vulnerable hydrogeological settings the likelihood of contamination and negative human impact will enhance. Table 1 provides some examples of when an improperly designed, sited, or maintained septic tank system negatively impacted human health. One example as summarised in Table 1, is the report by Borchardt et al. (2011) of an outbreak of acute gastroenteritis due to norovirus affecting 229 patrons and employees of a restaurant in Wisconsin (U.S.). The system followed approved guidelines for distances between septic systems and groundwater wells, which in this case provided water for the restaurant. Approved distances in general, often fail to account for local hydrogeological conditions. Epidemiological case-control analysis linked the consumption of the restaurant's well water with the illness, 
(odds ratio $=3.2(95 \%$ confidence level, confidence interval $=0.9$ to 11.4, $\mathrm{p}=0.06)$ (Borchardt et al., 2011).

Septic systems may however perform better in preventing groundwater contamination than a poorly maintained aerobic centralized wastewater treatment if they are well maintained and operated in line with the regulatory guidelines (Levett et al., 2010; DEA, 2010). Travis et al. (2010) reported an unadjusted hazard ratio of 0.85 (95\% Confidence Interval: Confidence Interval of 0.6 -
1.20) associated with Helicobacter pylori infection when comparing effluent from municipal wastewater treatment plants to a septic tank or cesspool. Another study found no significant association between giardiasis and exposure to discharge from septic systems (adjusted incidence rate ratio, aIRR 3.3; 95\% Confidence Interval 2.9 - 3.9) (Schnell et al., 2016).

Table 1. Health outbreak studies identified for this study that were associated with poor septic tank performance

\begin{tabular}{|c|c|c|c|c|}
\hline Country & Scenario & $\begin{array}{c}\text { Health } \\
\text { Outcome/ } \\
\text { Symptoms }\end{array}$ & $\begin{array}{c}\text { Cases } \\
\text { (Hospitalized } \\
\text { If Reported) }^{\mathbf{a}}\end{array}$ & References \\
\hline China $^{\mathrm{b}}$ & $\begin{array}{c}\text { Secondary } \\
\text { water supply } \\
\text { contamination } \\
\text { by septic tank } \\
\text { effluent }\end{array}$ & $\begin{array}{c}\text { Acute } \\
\text { gastroenteritis } \\
\text { (Norovirus) }\end{array}$ & $100^{\prime} \mathrm{s}^{\mathrm{a}}$ & $\begin{array}{l}\text { Li et al., } \\
2013\end{array}$ \\
\hline Oman $^{\mathrm{C}}$ & $\begin{array}{l}\text { Poor septic } \\
\text { tank } \\
\text { sanitation }\end{array}$ & $\begin{array}{c}\text { Shigellosis } \\
\text { (Shigella } \\
\text { flexneri) } \\
(\mathrm{P}<0.0001 ; \\
\text { odds ratio [OR] } \\
=4.86,95 \% \\
\text { confidence } \\
\text { interval }[\mathrm{CI}= \\
2.22 \text { to } 10.63)\end{array}$ & $\mathrm{UD}^{\mathrm{a}}$ & $\begin{array}{l}\text { Abaidani et } \\
\text { al., } 2015\end{array}$ \\
\hline
\end{tabular}




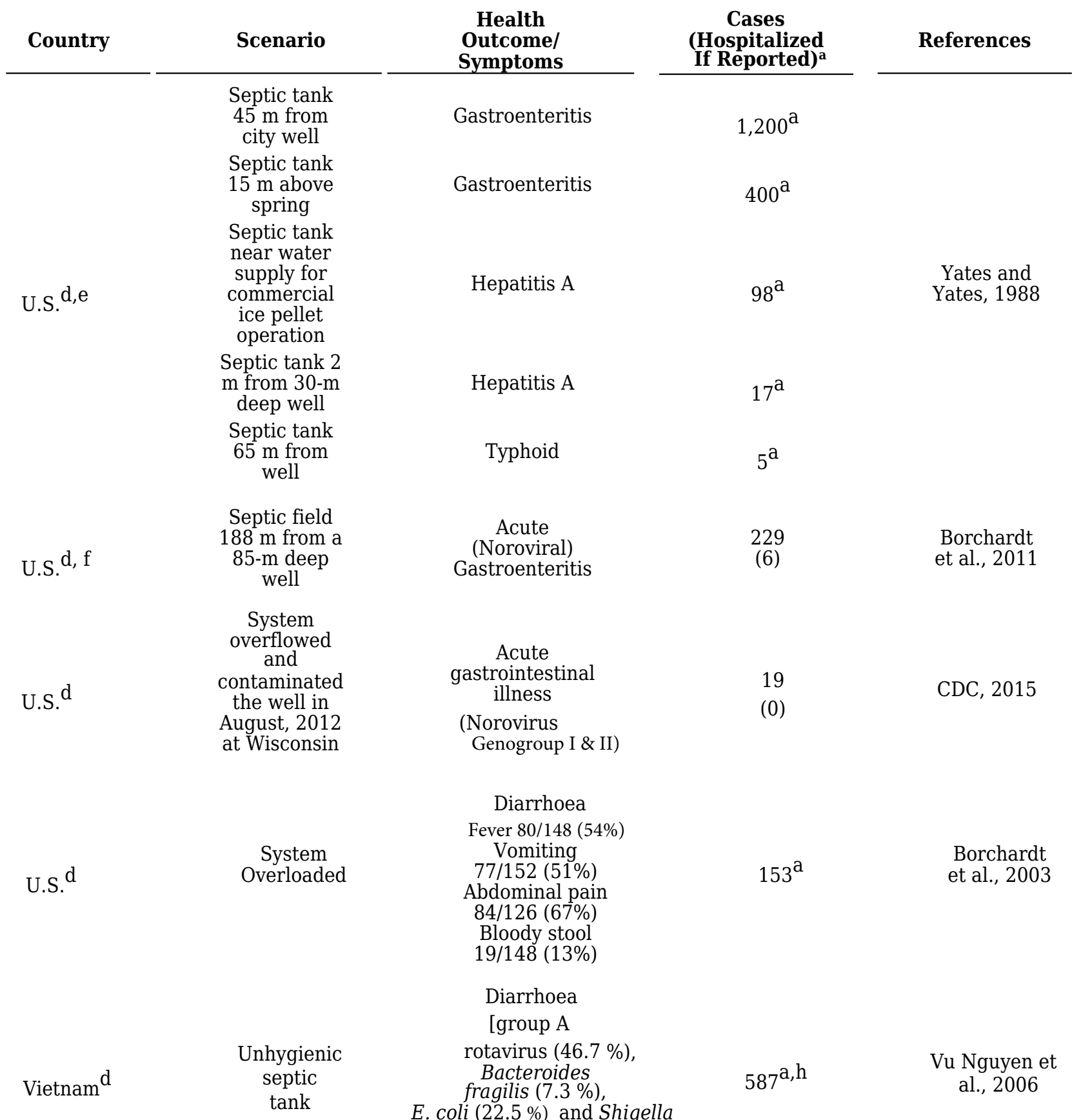

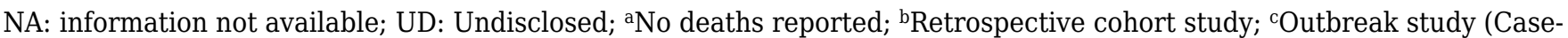
control study); ${ }^{\mathrm{O} O u t b r e a k}$ study; ${ }^{\mathrm{e}}$ Adapted from Stenström et al., 2011; ${ }^{\mathrm{f}}$ Septic system location complied with regulations; ghttp://www.cdc.gov/mmwr/preview/mmwrhtml/mm6431a2.htm\#Tab1; ${ }^{\text {hChildren }}$ 


\section{References}

Abaidani, I., Raju, P.A., Al-Shualli, I., Al-Sa'di, K., Al-Shaqsi, N. and Al-Khatri, A. (2015). Shigellosis Outbreak in Al Batinah South Governorate, Oman: Case-control study. Sultan Qaboos University Medical Journal. 15, pp. e382.

Anil, R. and Neera, A.L. (2016). Modified septic tank treatment system. Procedia Technology. 24, pp. $240-247$.

Appling, D., Habteselassie, M.Y., Radcliffe, D. and Bradshaw, J.K. (2013). Preliminary study on the effect of wastewater storage in septic tank on E. coli concentration in summer. Water. 5, pp. 1141-1151.

Banda, L.J., Mbewe, A.R., Nzala, S.H. and Halwindi, H. (2014). Effect of siting boreholes and septic tanks on groundwater quality in St. Bonaventure Township of Lusaka District, Zambia. International Journal of Environmental Sciences Toxic Research. 2, pp. 191-198.

Beal, C.D., Gardner, E.A., Kirchhof, G. and Menzies, N.W. (2006). Long-term flow rates and biomat zone hydrology in soil columns receiving septic tank effluent. Water Research. 40, pp. 2327-2338.

Beer, K.D., Gargano, J.W., Roberts, V.A., Hill, V.R., Garrison, L.E., Kutty, P.K. et al. (2015). Surveillance for waterborne disease outbreaks associated with drinking water-United States, 2011-2012. MMWR. Morbidity and Mortality Weekly Report. 64, pp. 842.

Bell, A., Layton, A.C., McKay, L., Williams, D., Gentry, R. and Sayler, G.S. (2009). Factors influencing the persistence of fecal Bacteroides in stream water. Journal of Environmental Quality. 38, pp. 1224-1232.

Bishop, H.G. and Inabo, H.I. (2015). Effects Of Well Casting, Septic System Distance And Topography On Incidences Of Giardia Lamblia And Entamoeba Histolytica In Wells Of Samaru-zaria, Nigeria. Applied Research Journal. 1(4), pp. 296-300.

Borchardt, M.A., Bradbury, K.R., Calvin, A.E., Kolberg, R.J., Alexander, S.C., Archer, J.R. et al. (2011). Norovirus outbreak caused by a new septic system in a dolomite aquifer. Groundwater. 49, pp. 85-97.

Borchardt, M.A., Chyou, P.H., DeVries, E.O. and Belongia, E.A. (2003). Septic system density and infectious diarrhea in a defined population of children. Environmental Health Perspectives. 111, pp. 742.

Bosch, A., Pinto, R.M. and Abad, F.X. (2006). Survival and transport of enteric viruses in the environment. Viruses in Foods. pp. 151-187.

Butler, D. and Davies, J.W. (2004). Urban Drainage. 2nd ed. Spon Press, London, UK.

Cave, B. and Kolsky, P. (1999). Groundwater, latrines and health. WELL Study.

Chabaud, S., Andres, Y., Lakel, A. and Le Cloirec, P. (2006). Bacteria removal in septic effluent: Influence of biofilm and protozoa. Water Research. 40, pp. 3109-3114.

Cooper, J.A., Loomis, G.W. and Amador, J.A. (2016). Hell and high water: Diminished septic system performance in coastal regions due to climate change. PloS One. 11, pp. e0162104.

DEA (2010). New Environmental Impact Assessment (EIA) Regulations come into effect today. Department of Environmental Affairs.

de Oliveira, J.M., Silva, S.H.G., de Menezes, M.D., Kämpf, N. and Curi, N. (2016). Land suitability for final waste disposal with emphasis on septic systems installation in southern Minas Gerais, Brazil. Ciência e Agrotecnologia. 40, pp. 37-45.

EPA, US (Submitted). Wastewater Technology Fact Sheet Disinfection for Small Systems. Office of Water, EPA 832F-03-024.

Franceys, R., Pickford, J. and Reed, R. (1992). A guide to the development of on-site sanitation. World Health Organization. 
Geneva, Switzerland.

Gill, L., Súilleabháin, C.O., Johnston, P. and Misstear, B. (2005). An Investigation into the Performance of Subsoils and Stratified Sand Filters for the Treatment of Wastewater from On-site Systems (2001-MS-15-M1).

Harrison, R.B., Turner, N.S., Hoyle, J.A., Krejsl, J., Tone, D.D., Henry, C.L. et al. (2000). Treatment of septic effluent for fecal coliform and nitrogen in coarse-textured soils: Use of soil-only and sand filter systems. Water, Air, and Soil Pollution. 124, pp. 205-215.

Heger, S. (2017). High temperature impacts onsite wastewater treatment.

Heinonen-Tanski, H. and Savolainen, R. (2003). Disinfection of septic tank and cesspool wastewater with peracetic acid. AMBIO: A Journal of the Human Environment. 32, pp. 358-361.

Heistad, A., Seidu, R., Flø, A., Paruch, A.M., Hanssen, J.F. and Stenström, T.A. (2009). Long-term hygienic barrier efficiency of a compact on-site wastewater treatment system. Journal of Environmental Quality. 38, pp. 2182-2188.

Jiménez, B., Mara, D., Carr, R. and Brissaud, F. (2010). Wastewater treatment for pathogen removal and nutrient conservation: suitable systems for use in developing countries. Wastewater Irrigation and Health. Assessing and Mitigating Risk in Low-Income Countries. pp. 149-169.

Kadam, A.M., Oza, G.H., Nemade, P.D. and Shankar, H.S. (2008). Pathogen removal from municipal wastewater in constructed soil filter. Ecological Engineering. 33, pp. 37-44.

Katz, B.G., Griffin, D.W., McMahon, P.B., Harden, H.S., Wade, E., Hicks, R.W. et al. (2010). Fate of effluent-borne contaminants beneath septic tank drainfields overlying a karst aquifer. Journal of environmental quality. 39, pp. 1181-1195.

Keegan, M., Kilroy, K., Nolan, D., Dubber, D., Johnston, P.M., Misstear, B.D.R. et al. (2014). Assessment of the impact of traditional septic tank soakaway systems on water quality in Ireland. Water Science and Technology. 70, pp. 634-641.

Kristiansen, R. (1981). Sand-Filter Trenches for Purification of Septic Tank Effluent: I. The Clogging Mechanism and Soil Physical Environment 1. Journal of Environmental Quality. 10, pp. 353-357.

Levett, K.J., Vanderzalm, J.L., Page, D.W. and Dillon, P.J. (2010). Factors affecting the performance and risks to human health of on-site wastewater treatment systems. Water Science and Technology. 62, pp. 1499-1509.

Li, Y., Guo, H., Xu, Z., Zhou, X., Zhang, H., Zhang, L. et al. (2013). An outbreak of norovirus gastroenteritis associated with a secondary water supply system in a factory in south China. BMC Public Health. 13, pp. 283.

Lusk, M., Toor, G.S. and Obreza, T. (2014). Onsite Sewage Treatment and Disposal Systems: Bacteria and Protozoa. SL350 Serie of the Soil and Water Science Department, UF/IFAS Extension.

Marañón, E., Castrillon, L., Fernández, J.J., Fernández, Y., Peláez, A.I. and Sánchez, J. (2006). Anaerobic mesophilic treatment of cattle manure in an upflow anaerobic sludge blanket reactor with prior pasteurization. Journal of the Air and Waste Management Association. 56, pp. 137-143.

Mbuligwe, S.E. (2005). Applicability of a septic tank/engineered wetland coupled system in the treatment and recycling of wastewater from a small community. Environmental Management. 35, pp. 99-108.

Nguyen, T.V., Le Van, P., Le Huy, C., Gia, K.N. and Weintraub, A. (2006). Etiology and epidemiology of diarrhea in children in Hanoi, Vietnam. International Journal of Infectious Diseases. 10, pp. 298-308.

Nicosia, L.A., Rose, J.B., Stark, L. and Stewart, M.T. (2001). A field study of virus removal in septic tank drainfields. Journal of Environmental Quality. 30, pp. 1933-1939.

Nnaji, C.C. and Agunwamba, E. (2011). Improving Septic Tank Performance By A New Rational Design Approach. 
NOAA (2011). State of the coast: the U.S. population living at the coast. NOAA.

Okoh, A.I., Sibanda, T. and Gusha, S.S. (2010). Inadequately treated wastewater as a source of human enteric viruses in the environment. International Journal of Environmental Research and Public Health. 7, pp. 2620-2637.

Otis, R.J., Boyle, W.C., Clements, E.V. and Schmidt, C.J. (1980). Design manual onsite wastewater treatment and disposal systems. EPA technology transfer seminar publication. US Environmental Protection Agency (EPA), Municipal Environmental Research Laboratory. Cincinnati, OH, USA. pp. 412.

Pang, L., Close, M., Goltz, M., Sinton, L., Davies, H., Hall, C. et al. (2003). Estimation of septic tank setback distances based on transport of E. coli and F-RNA phages. Environment International. pp. 907-921.

Papadopoulos, F.H., Tsihrintzis, V.A. and Zdragas, A.G. (2011). Removal of faecal bacteria from septage by treating it in a full-scale duckweed-covered pond system. Journal of Environmental Management. 92, pp. 3130-3135.

Pundsack, J., Axler, R., Hicks, R., Henneck, J., Nordman, D. and McCarthy, B. (2001). Seasonal pathogen removal by alternative on-site wastewater systems. Water Environment Research. 73, pp. 204-212.

Pundsack, J., Axler, R., Hicks, R., Henneck, J., Nordman, D. and McCarthy, B. (2001). Seasonal pathogen removal by alternative on-site wastewater treatment systems. Water Environment Research. 73, pp. 204-212.

Purnell, S., Ebdon, J., Buck, A., Tupper, M. and Taylor, H. (2016). Removal of phages and viral pathogens in a full-scale MBR: implications for wastewater reuse and potable water. Water Research. 100, pp. 20-27.

Richards, S., Paterson, E., Withers, P.J.A. and Stutter, M. (2016). Septic tank discharges as multi-pollutant hotspots in catchments. Science of the Total Environment. 542, pp. 854-863.

Schnell, K., Collier, S., Derado, G., Yoder, J. and Gargano, J.W. (2016). Giardiasis in the United States - an epidemiologic and geospatial analysis of county-level drinking water and sanitation data, 1993-2010. Journal of Water and Health. 14, pp. 267-279.

Sharma, M.K. and Kazmi, A.A. (2016). Performance evaluation of a single household anaerobic packaged system for onsite domestic wastewater treatment. Desalination and Water Treatment. 57, pp. 9216-9225.

Sharma, M.K., Khursheed, A. and Kazmi, A.A. (2014). Modified septic tank-anaerobic filter unit as a two-stage onsite domestic wastewater treatment system. Environmental Technology. 35, pp. 2183-2193.

Siegrist, R., Tyler, J.E. and Jenssen, P.D. (2000). Design and performance of onsite wastewater soil absorption systems. White paper. Prepared for National Needs Conference, Risk-Based Decision Making fo Onsite Wastewater Treatment. Washington University. St. Louis, Missouri. pp. 19-20.

Sowah, R.A., Habteselassie, M.Y., Radcliffe, D.E., Bauske, E. and Risse, M. (2017). Isolating the impact of septic systems on fecal pollution in streams of suburban watersheds in Georgia, United States. Water Research. 108, pp. 330-338.

Stenström, T.A., Seidu, R., Ekane, N. and Zurbrügg, C. (2011). Microbial exposure and health assessments in sanitation technologies and systems. Stockholm Environment Institute (SEI) Stockholm.

Stevik, T.K., Aa, K., Ausland, G. and Hanssen, J.F. (2004). Retention and removal of pathogenic bacteria in wastewater percolating through porous media: a review. Water Research. 38, pp. 1355-1367.

Thingstad, T.F. (2000). Elements of a theory for the mechanisms controlling abundance, diversity, and biogeochemical role of lytic bacterial viruses in aquatic systems. Limnology and Oceanography. 45, pp. 1320-1328.

Tilley, E., Ulrich, L., Lüthi, C., Reymond, P. and Zurbrügg, C. (2014). Compendium of Sanitation Systems and Technologies. 2nd Revised Edition. Swiss Federal Institute of Aquatic Science and Technology (Eawag). Dübendorf, Switzerland.

Travis, P.B., Goodman, K.J., O'Rourke, K.M., Groves, F.D., Sinha, D., Nicholas, J.S. et al. (2010). The association of drinking water quality and sewage disposal with Helicobacter pylori incidence in infants: the potential role of water-borne 
transmission. Journal of Water and Health. 8, pp. 192-203.

Uebler, R.L. (1982). Design of Low-Pressure Pipe Wastewater Treatment Systems. 1982 Southeastern On-Site Sewage Treatment Conference Proceedings. North Carolina Division of Health Services and the Soil Science Department. North Carolina State University.

Unc, A. and Goss, M.J. (2003). Movement of faecal bacteria through the vadose zone. Water, Air, and Soil Pollution. 149, pp. 327-337.

USEPA (1992). Guidelines for Water Reuse. United States Environmental Protection Authority (1992). EPA/625/R-92/004.

Vijay, R., Khobragade, P. and Mohapatra, P.K. (2011). Assessment of groundwater quality in Puri City, India: an impact of anthropogenic activities. Environmental Monitoring and Assessment. 177, pp. 409-418.

Vinnerås, B., Nordin, A., Niwagaba, C. and Nyberg, K. (2008). Inactivation of bacteria and viruses in human urine depending on temperature and dilution rate. Water Research. 42, pp. 4067-4074. doi: http://dx.doi.org/10.1016/j.watres.2008.06.014.

Wallace, S. (2000). Drip irrigation design and installation recommendations. Minnesota Onsite Sewage Treatment Contractors Association. Proceedings of the MOSTCA Annual Meeting. St. Paul MN.

WHO (2006). Volume II of the Guidelines for the safe use of wastewater, excreta and greywater: Wastewater use in agriculture. World Health Organization. France. pp. 196.

Wolf, L., Klinger, J., Held, I. and Hötzl, H. (2006). Integrating groundwater into urban water management. Water Science and Technology. 54, pp. 395-403.

Yates, M.V. and Yates, S.R. (1988). Virus survival and transport in groundwater. Water Science and Technology. 20, pp. 301-307.

Zhang, H., Nordin, N.A. and Olson, M.S. (2013). Evaluating the effects of variable water chemistry on bacterial transport during infiltration. Journal of Contaminant Hydrology. 150, pp. 54-64. 